\title{
Strengthen Security and Public Order: Accountability Management in Improving the Quality of Law Enforcement
}

\author{
Erlyn Indarti \\ Diponegoro University, \\ Indonesia
}

Doi: 10.36941/ajis-2020-0025

\section{Abstract}

In the framework of Democratic Policing Reforms, since 1979 the United Nations has actually adopted what is called the Code of Conduct for Law Enforcement Officials. This Code of Conduct includes the idea that the police should represent and be accountable to the entire community. Within the Indonesian case, it is recognized that there is a red thread between supervision and accountability of police performance, particularly law enforcement. However, more than a decade since police reform began in Indonesia, the demands of the wider community for accountability in carrying out police duties, particularly law enforcement in discretionary cases, have continued to echo. In order to make the supervision more effective, it is necessary to examine how supervision of law enforcement by the National Police is carried out. This article is written as a comparative literature study in the realm of legal philosophy. The results reveal that Law enforcement by the National Police, especially with regard to discretionary cases, turns out to require police accountability both inside and outside, both individually and organizationally. In this situation, supervision was carried out in the form of supervision of the implementation of law enforcement by the National Police. In this case, accountability can be said to be a kind of 'soul mate' from supervision.

Keywords: law enforcement, supervision, management, police

\section{Introduction}

As a manifestation of the attention of world bodies on what is called Democratic Policing Reforms which leads to an increase in the role of the police in the process of democratization and respect for human rights- since 1979, the UN has actually adopted the Code of Conduct for Law Enforcement Officials, which includes the idea that the police should represent, be monitored and accountable to the entire community (Indarti, 2007; see. Grant, 2002). This code has been translated into basic values for the police in various contexts. Celador (2005) analyzes police reform through peace building efforts through the application of the value of 'democratic policing. By taking case studies in Northern Ireland, Ellison (2007) provides a blueprint for democratic policing in the context of political transition, and conflict resolution. Stone and Ward (200o) also provide an action framework for democratic policing. Neild (2001) also provides a scientific basis for democratic national reforms for war-torn societies. In this connection, there are at least seven criteria for Democratic Policing (Das \& Marenin, 2000), that are rule of law, public accountability, transparent decision making, public participation, minimum use of force, respect for human rights, and democracy, both internally and externally in the organization. Police supervision is often coupled with 'supervision' of police 
performance. In general, police performance includes public services, order maintenance, and law enforcement. Following this line of thought, it is understandable that contemporary policing analists suggest that supervision and accountability of police performance, especially law enforcement is highly related (see Kratcoski, 2017; Wentkowska, 2016).

In Indonesia, the supervision function in the form of '(functional) supervision' of the Indonesian National Police (abbreviate: Polri), basically carried out by the National Police Commission (abbreviate: Kompolnas) as stated in the Explanation of Law No. 2/2002 about the National Police, General Section. In a broader understanding, Kompolnas' oversight of the National Police basically covers the entire component of efforts to achieve the objectives of the National Police as stated in Article 4 of Law No. 2/2002, including law enforcement. Meanwhile, decisions made or steps taken when the police are dealing with a case or problem that exists in the community basically have gone through a relatively strict 'professional consideration'. This whole set of processes is said to be discretion. The steps or decisions taken are the results of discretion. What needs to be emphasized is that all of this involves the accountability of the police concerned to the organization and the community it serves (Indarti, 2000). In the context of accountability like this, supervision of the implementation of police duties is needed. However, more than a decade since police reform began in Indonesia, the complexity of legal issues, particularly law enforcement, has been increasing. In line with this, the demands of the wider community for accountability in carrying out police duties continue to echo. For this reason, in order to make the supervision more effective, it is necessary to examine how supervision of law enforcement by the National Police is carried out.

By taking the object on the realm of legal philosophy with a comparative model, the study is about the Police and this supervision of law enforcement carried out by the National Police was held as a literature review (Sudarto, 1997). The rules of philosophy of research methodology are followed because legal philosophy is in general more a part of philosophy (Darmodiharjo \& Shidarta, 1999).

\section{Democratic Policing Reforms in International Perspectives}

There are two concepts in the term about the police. The first concept is policing as a process, and the second is the police as an institution. Mawby (2012) distinguishes between policing and the police. Policing refers to efforts to prevent and detect crime and maintain public order. In this process, the involvement of a number of institutions or individuals may be needed in the implementation of activities. On the other hand, the police refer to it as an institution that is responsible for a range of services, including crime and interference (Mawby 2012). For the concept of policing, there are many opinions that state that this process is closely connected with the authorization of duties, responsibilities, accountability and police management. Stone and Ward (2000) state that democratic policing is connected with structural responsibility with various authorities and the public at various levels of control. The existence of this responsibility will distinguish between democratic police from the police governed by the regime (Stone and Ward, 2000). Bradford and Quinton (2014) analyze the confidence of police officers with their own authority and the factors that influence their feelings about their legitimacy. The findings of Bradford and Quinton (2014) highlight that identification with their organizations and perceptions of procedural fairness of senior management are the strongest predictors of trust in police authority. A stronger sense of self-legitimacy encourages commitment to the application of democratic policing. With regard to the effects of self-legitimacy on ways of thinking about policing, Bradford and Quinton (2014) state that this sense of legitimacy, in police organizations, is embedded in the 'matrix of identity' and 'cultural adaptation'.

Jackson and Lyon (2001) state that the need for rehabilitation of police institutions is a crucial element for building a productive and peaceful society. It is related that the police are the most visible right hand of government for civilians (Wiatrowski \& Goldstone, 2010). In countries with authoritarian leadership, the police are widely used as a means to protect the regime and to pressure opposition groups to intimidate ordinary citizens. For this reason, the concept of democratic policing 
is needed to show that the tasks of the police are regulated and connected by the authorities in a convincing and legitimate manner, and are not directed to carry out missions outside their duties as servants and protectors of the community. Jackson and Lyon (2001) further explained that democratic policing is basically indispensable in societies with the possibility of conflict and high ethnic tension to enforce law firmly and create a conducive community environment. In a community context like this, there are four important elements for policing identified by Jackson and Lyon (2001), namely people's perceptions about law enforcement, the political environment, police culture, and democratic participation. In addition, in contrast to stable countries, countries with high ethnic tension are also connected to the structure of law enforcement. Thus, the creation of police structures and accountability through democratic policing can prevent the use of police institutions by authoritarian governments to engage in violence.

However, the concept of democratic policing, and its application in developing countries, is not a linear and uniform concept. This application was initially introduced in the 1970s, having various characteristics in each country according to the structure and culture of the law at the local level. Bonner (2019) presents the classification that there are at least four types of democratic policing, namely right, center-right, center-left and left. Furthermore, Bonner (2019) explains that democratic policing is multidimensional and multilevel and is not free from ideology and political pressure in some cases of application, such as in Latin American countries in the 1980s and 1990s. This is also in line with the argument of Wiatrowski (2016) who questions the possibility of democratic policing in transitional and developing societies. Wiatrowski (2016) argues that the adoption of democratic policing by countries that make democratic transitions is not entirely successful due to differences in the legal and structural frameworks of policing models and practices promoted in the West. This shows that community policing in developing countries and democratic transitions is often inadequate due to the state's weakness in providing a legal and management framework for overseeing police duties and authority. Manning (2015) also said that the role and application of policing around the world in theory and practice is more likely to be different from policing in the United States and among Western democracies.

However, several studies have confirmed that there are some crucial elements connected with democratic policing. Stone and Ward (200o) explain that accountability structures, structures at the internal level of police institutions, oversight at the local level and social involvement are needed in the adoption of democratic policing. Structures are needed to provide a clear platform of police responsibility and oversight of police behavior in order to secure the public. In addition, stronger coordination and linkages of these structures are needed to ensure stronger and more effective accountability for police work. Sklansky (2005) explains that democratic policing is connected with the interests and institutional perceptions of police organizations in reconciling law enforcement with the aim and in accordance with the principles of democratic society. In addition, police reform is also closely connected with the reform of police law regulations. From the aspect of resource management, police reform is closely connected with the attitude of police professionalism, assignment of duties, responsibilities and authority of the police. Sklansky (2005) ideally states that democratic policing is external, where it is not intended to bring democratic benefits to the police officers themselves, but to guarantee accountability and democratic principles for law enforcement. Regarding the structure and institutions that authorize policing, Friedman and Pnomarenko (2015) explain that democratic policing is connected with authorization in enforcing the law by police organizations. Furthermore, Friedman and Pnomarenko (2015) suggest that supervision for authorization requirements must be carried out by the court through a series of interpretive techniques, including identifying the right to police authority and preventing authority and refusing authority to continue until the proper authorization is obtained. The basic argumentation of Friedman and Pnomarenko (2015) is that policing must be rationalized and treated the same as administrative practices. This is to avoid excessive authority from the police in carrying out their duties. In addition, the authorization is to disclose the confidentiality of the police except in certain operational contexts that are considered sensitive and crucial. This is related to the next element in 
democratic policing, namely transparency which in this context needs to be considered as a broad part of democratic governance. In addition, it is important, police reform must also rehabilitate the constitutional and administrative legal framework (Friedman and Pnomarenko, 2015).

As part of public administration, the framework for implementing democratic policing is also considered as a new public management (NPM). This is because the administration of the police has long been neglected and is considered not very influential for the improvement of public services widely, except in areas related to crime. Taking objects in transitional, developing and post-conflict countries, Den Heyer (2011) explores a new public management perspective (NPM) as the main strategy for democratic police reform. As one of the strategies in police reform, new public management can be applied to the adoption of democratic policing and community policing by specifically having to pay attention to the culture and limitations of local abilities in its implementation. The benefits of adopting democratic policing in developing countries have been widely discussed. Wiatrowski and Goldstone (2010) state that democratic policing can contribute to the establishment of stable democratic regimes in post-conflict countries. This is in addition to the main task of the police to protect the community from crime, serve civil society and build a safe community. Celador (2005) also states that democratic policing can be utilized in manipulating social change, improving morale and efficiency of police duties.

\section{Achieving the Goals of the National Police}

Article 4 of Law No. 2 of 2002 states that the National Police of the Republic of Indonesia aims to realize internal security which includes the maintenance of public security and order, orderly and upholding the law, the implementation of protection, protection and community services, and the establishment of public peace by upholding human rights. The essence of the scope of the objectives of the National Police includes maintenance of security and public order, law enforcement, and protection and service to the community. It is probable that this change in the order of writing was inspired by the spirit of community policing which was a reaction to 'modern' policing (some people actually called it 'traditional') which prioritized or prioritized thus reducing the police become just 'law enforcement' (Indarti, 2007). In order to achieve the objectives of the police, the Indonesian National Police enforces the law. However, it needs to be realized, both when it is made and when used, the law cannot be separated from what humans and the community do to it. It is loaded with touches and outpouring the values or construction of the ideas of the makers and users. Therefore, making, implementing or enforcing a law that is truly free from the interference of taste, inner atmosphere, and consideration of human reason is unlikely (Indarti, 200o).

Since law is an indispensable instrument of social control, the law becomes the core through people's efforts to interpret and understand it and through the way they use and enforce it (Indarti, 2000). When a law enforcer is faced with a case or problem that exists in the community, independence and the authority or authority inherent in him enables him to (usually individually) be able to do a variety of different jobs wisely and considerably, namely (Indarti, 200o) reading the case or problem properly, translating existing laws comprehensively, interpreting the law that has been translated, sorting cases/laws, choosing or set a choice, makin a decision or conclusion, and/or taking certain actions or steps. In terms of law enforcement, decisions that have been made and/or actions that have been taken can lead to the application of certain laws. Finally, what needs to be emphasized is that however, the various diverse jobs involve the accountability of the individual law enforcers concerned with their organizations and the communities they serve. Thus, for a law enforcer, in carrying out his duties, the decisions made or any steps taken should have gone through a relatively strict 'professional consideration'. This whole series of processes that take place in a fairly wide range of motion is said to be 'discretion'. The steps or decisions taken are the results of 'discretion' (Indarti, 200o). The application of police discretion as outlined above, especially in terms of law enforcement, requires accountability of the police both inside and outside, both individually and organizationally. For this reason, supervision was carried out in the form of supervision of the implementation of law 
enforcement by the National Police (see. Correia \& Jenks, 2011).

\section{Police, Supervision and Accountability}

Responsibility or obligation to act refers to the obligation of (an individual/legal entity/collective leadership of an organization) to make policies/decisions and/or take actions/steps (where making policies/decisions and/or taking actions/steps that have not occurred). Accountability is obligation to answer, that is the obligation of (an individual/legal entity/collective leader of an organization) to answer questions about (which can basically be interpreted as responsible answer to making policies/decisions and/or taking actions/steps that have occurred. Accountability, in general, including police accountability in particular, can be studied, highlighted, or understood through various channels of understanding or say various perspectives (for broader discussion, see. Bivins, 2006; Pompper, 2015). First of all it is based on who is 'accountable' or who is obliged to convey accountability. In this case, the accountability of the police is divided into some aspects (Indarti, 2005), there are individual accountability, collective accountability, and organizational accountability (for more detailed discussion about these kinds of accountability, see. Kroon et al., 1991; Morris \& Moore, 200o). Moreover, based on the delivery direction/orientation, police accountability consists of internal and external accountability (Indarti, 2005). Internal or inward accountability was carried out within the police organization itself, from the national level to the lowest, in accordance with its level. External accountability was delivered by a police organization to other parties as recipients of accountability in accordance with applicable laws and regulations with an example being that the police accountability submitted to the the Parliament.

Hence, police accountability can be understood according to its nature. According to this understanding, the police accountability will include personal or closed accountability; and public or open accountability (Indarti, 2005; Walker, 2001; Kelling et al., 1988). In terms of personal or closed police accountability, the submission of accountability is not intended to be known by/in general. This process of accountability will thus proceed in a closed manner. Conversely, when existing accountability is general, it is the public's right to be able to obtain information about this freely (Suhartono, 2018). Moreover, the course of the accountability process is indeed open. Within the scope of policing, public accountability is said to be highest accountability because it is possible to carry it out in it (Indarti, 2008). These processes can be divided into some aspects, such as the process of 'dialogue-dialectics' between the police and the public. Second process is related to the process of 'control and support. Public control over the possibility of abuse of power and/or authority mandates received, held, carried out, or carried out by the police, and support from the public for to improve the performance or performance of the police as a party that has an obligation to convey accountability to the entire community as a creditor (for this, see. Skolnick \& Fyfe, 1993). Third process is related to the democratic process is actually a consensus, distillation, or resultant spelling of a meeting or conflict of interest, opinion, perception, or construction between the police, on the one hand, and the public, on the other hand. Lastly, there is a process of development of mutual understanding, appreciation, trust, equality, belonging, sense of belonging, unity and unity, or the unity between police, and public. However it is understood and from any angle police accountability is seen or approached, for the police, both as individuals and organizations, all the accountability categorizations of the police above operate simultaneously, which basically speaks to what is called 'supervision'.

\section{Conclusion}

In order to enhance the role of the police in the process of democratization and respect for human rights, since 1979 the United Nations has adopted the so-called Code of Conduct for Law Enforcement Officials. This Code of Conduct includes the idea that the police should represent, be monitored, and accountable to the entire community. The need for supervision of the 
implementation of police duties is felt increasingly urgent when it comes to discretionary cases. In Indonesia, the supervision function in the form of '[functional] supervision' of the Indonesian National Police (Polri), basically carried out by the National Police Commission (Kompolnas) as stated in the Explanation of Law Number 2 of 2002 (Law No. 2/2002) about the National Police, General Section. In a broader understanding, Kompolnas' oversight of the National Police basically covers the entire component of efforts to achieve the objectives of the National Police as stated in Article 4 of Law No. 2/2002, including law enforcement. However, since the start of police reform in Indonesia more than a decade ago, the complexity of the problem of law enforcement has been increasing. The demands of the wider community for accountability in carrying out police duties continued.

For this reason, in order to make the supervision more effective, the study of 'oversight of law enforcement by the Indonesian Police' was carried out. Meanwhile, Article 4 of Law No. 2 of 2002 states that the National Police of the Republic of Indonesia aims to realize internal security which includes the maintenance of public security and order, orderly and upholding the law, the implementation of protection, protection and community services, and the establishment of public peace by upholding human rights. The essence of the scope of the objectives of the National Police includes: maintenance of security and public order; law enforcement; and protection, protection and service to the community. Law enforcement by the National Police, especially with regard to discretionary cases, turns out to require police accountability both inside and outside, both individually and organizationally. In this situation, supervision was carried out in the form of supervision of the implementation of law enforcement by the National Police. In this case, accountability can be said to be a kind of 'soul mate' from supervision. Both are like two sides of the same coin. For the police, both as individuals and organizations, all the accountability categorizations of the police above operate simultaneously, to then respond to what is referred to as 'supervision'.

\section{References}

Bivins, T. H. (2006). Responsibility and accountability. Ethics in public relations: Responsible advocacy, 19-38.

Bonner, M. D. (2019). What democratic policing is... and is not. Policing and society, 1-17.

Bradford, B., \& Quinton, P. (2014). Self-legitimacy, police culture and support for democratic policing in an English constabulary. British journal of criminology, 54(6), 1023-1046.

Celador, G. C. (2005). Police reform: Peacebuilding through 'democratic policing'?. International peacekeeping, 12(3), 364-376.

Correia, M. E., \& Jenks, D. A. (2011). Expectations of change: The congruency between beat officers and supervisors and its impact on programmatic change. Police Practice and Research: An International Journal, 12(1), 16-34.

Darmodiharjo, D. \& Shidarta (1999). Pokok-Pokok Filsafat Hukum. Jakarta: Gramedia Pustaka Utama.

Das, D., \& Marenin, O. (200o). Challenges of policing democracies. Challenges of policing democracies: A world perspective, 3-23.

Den Heyer, G. (2011). New public management: A strategy for democratic police reform in transitioning and developing countries. Policing: An International Journal of Police Strategies E Management, 34(3), 419-433.

Ellison, G. (2007). A blueprint for democratic policing anywhere in the world? Police reform, political transition, and conflict resolution in Northern Ireland. Police quarterly, 10(3), 243-269.

Friedman, B., \& Pnomarenko, M. (2015). Democratic policing. NYUL Rev., 90, 1827.

Grant, J. K. (2002). Ethics and law enforcement. FBI L. Enforcement Bull., 71, 11.

Indarti, E. (200o). Diskresi Kepolisian. Semarang: Badan Penerbit Undip.

Indarti, E. (2005). Kekuasaan, Otoritas, dan Akuntabilitas Kepolisian: Suatu Pemahaman dan Penjabaran Baru Hukum Kepolisian. Semarang: Badan Penerbit Undip.

Indarti, E. (2007, May 23). Menabur Profesionalisme dan Kemandirian, Menuai Legitimasi: Sebuah Transformasi Menuju Community Policing as Democratic Policing. Paper presented at the National Seminar on Police Reform and Professionalism, National Police Headquarters, Jakarta.

Indarti, E. (2008, April 17). Pengawasan Eksternal Dan Akuntabilitas Kepolisian. Paper presented at the Seminar on Police Accountability, Jayapura.

Jackson, A., \& Lyon, A. (2001). Policing after ethnic conflict: Culture, democratic policing, politics, and the public. Policing: An International Journal of Police Strategies E Management, 24(4), 563-585. 
Kelling, G. L., Wasserman, R., \& Williams, H. (1988). Police accountability and community policing (Vol. 7). Washington, DC: US Government Printing Office.

Kratcoski, P. C. (2017). Policing: Continuity and Change. In Global issues in contemporary policing (pp. 29-58). CRC Press.

Kroon, M. B., Hart, P. T., \& Van Kreveld, D. (1991). Managing group decision making processes: Individual versus collective accountability and groupthink. International Journal of Conflict Management, 2(2), 91-115.

Manning, P. K. (2015). Democratic policing in a changing world. Routledge.

Mawby, R. I. (2012). Models of policing. In Handbook of policing (pp. 45-74). Willan.

Morris, M. W., \& Moore, P. C. (200o). The lessons we (don't) learn: Counterfactual thinking and organizational accountability after a close call. Administrative Science Quarterly, 45(4), 737-765.

Neild, R. (2001). Democratic police reforms in war-torn societies. Conflict, Security \& Development, 1(o1), $21-43$.

Pompper, D. (2015). Corporate social responsibility, sustainability and public relations: Negotiating multiple complex challenges. Routledge.

Sklansky, D. L. (2005). Democratic policing inside and out. unpublished paper.

Skolnick, J. H., \& Fyfe, J. J. (1993). Above the law: Police and the excessive use of force (pp. 198-205). New York: Free Press.

Stone, C. E., \& Ward, H. H. (200o). Democratic policing: A framework for action. Policing and Society: An International Journal, 10(1), 11-45.

Stone, C. E., \& Ward, H. H. (200o). Democratic policing: A framework for action. Policing and Society: An International Journal, 10(1), 11-45.

Sudarto (1997). Metodologi Penelitian Filsafat. Jakarta: RajaGrafindo Persada.

Suhartono, S. (2018). Confidentiality and Public Information: Resolving Administrative Dispute about Public Information Disclosure. Journal of Legal, Ethical and Regulatory Issues, 21(SI).

Walker, S. (2001). Police accountability. Belmont, CA: Wadsworth, 199-214.

Wentkowska, A. (2016). Let Us Be Judged By Our Actions Oversight Mechanisms of Policing in Comparative Outline. Polish Rev. Int'l \& Eur. L., 5, 45.

Wiatrowski, M. D. (2016). Democratic policing in transitional and developing countries. Routledge.

Wiatrowski, M. D., \& Goldstone, J. A. (2010). The ballot and the badge: democratic policing. Journal of democracy, 21(2), 79-92. 